\title{
Genetic Diversity and Demography of Skipjack Tuna (Katsuwonus pelamis) In Southern and Western Part of Indonesian Waters
}

\author{
Irwan Jatmiko*, Raymon R. Zedta, Maya Agustina and Bram Setyadji \\ Research Institute for Tuna Fisheries \\ J. Mertasari 140, Sidakarya, Denpasar, Bali, Indonesia 80224 \\ Email: irwan.jatmiko@gmail.com
}

\begin{abstract}
Skipjack tuna (Katsuwonus pelamis) is highly migratory species that spread from trophic and sub trophic waters. This species can be found in Atlantic, Indian and Pacific oceans. The genetic information of highly migratory species like skipjack tuna is important to support the sustainability of the fisheries. The objectives of this study are to gain information genetic diversity and population structure of exploited species and to understand the population kinship in Indonesian waters. Tissue samples were collected from six locations, i.e.: Sibolga (North Sumatera), Padang (West Sumatera), Binuangeun (Banten), Pacitan (East Java), Lombok (West Nusa Tenggara) and Kupang (East Nusa Tenggara). Microsatellite analysis was done in this study consisting of extraction, purification, polymerase chain reaction (PCR) amplification and electrophoresis. Three loci used for the analysis i.e.: UTD 172, UTD 523 and UTD 535. The results showed that there are two groups from six locations i.e.: group 1: Sibolga and Padang; group 2: Binuangeun, Pacitan Lombok and Kupang. The variance among these two groups is 0.066 with variance $5.441 \%$. This finding in line with Indonesian Fisheries Management Area of 572 (west of Sumatera waters) and 573 (south of Java waters). However, as highly migratory species across nations, the management strategy for skipjack tuna needs collaboration among countries through regional fisheries management authority like Indian Ocean Tuna Commission (IOTC).
\end{abstract}

Keywords: population structure, Tuna fish, microsatellite analysis

\section{Introduction}

Skipjack tuna (Katsuwonus pelamis) is a cosmopolitan pelagic fish and could be found in with in both tropical and subtropical waters of the three major oceans, e.g. Indian, Pacific and Atlantic Oceans (Fujino et al., 1981). It is highly productive (Grande et al., 2014) with length at maturity $43 \mathrm{~cm}$ (Jatmiko et al., 2015) and has a maximum age below 4.5 y (Jin et al., 2015). It is also considered as an important fisheries commodity in Indonesia, especially in small-scale fisheries (Setiyawan, 2016; Nurdin and Nugraha, 2017; Setyadji et al., 2018). Based on Indian Ocean Tuna Commission (IOTC) database, the exploitation of skipjack by Indonesian fleets has been conducted since early 1950s. The catch estimation of skipjack is rising up from only $\sim 500$ tons in 1950 to $~ 92,000$ tons in 2013. However, the catch is declining and reach stable posture around 76,000-78,000 tons during 20142016 (IOTC, 2018).

Skipjack interacted with various gears such as hand line, troll line, purse seine, gillnet, longline and pole and line. Therefore, it susceptible to local overfishing as intensive fishing occurred throughout the years, especially in western and southern part of Indonesian waters (Rochman et al., 2015; Zedta et al., 2018). No specific stock assessment conducted yet for skipjack either in western or southern part of Indonesia, but the initiative has begun in its territorial and archipelagic waters (Satria and Sadiyah, 2018). Determining the stock distribution or origin is essential before conducting any stock assessment, because it will shape the most suitable harvest control rules.

Population structure in population genetics is explaining the management unit of the population (stock) of fish. Several approaches have been taken to explain the condition of fish population structure, including phylogeny, genetic relationships and genetic variation among populations (Jatmiko, et al., 2018; Barth et al., 2017; Iranawati, 2014). Previous genetic stock structure studies on skipjack revealed a close relationship between Atlantic and Pacific stock (Ely et al., 2005; Graves et al., 1984) but distinct with Indian Ocean stock (Fujino et al., 1981; Menezes et al., 2006). A few "localized" genetic study also conducted by Dammannagoda et al. (2011) in Northwestern Indian Ocean, which found two distinguishable stocks mixed in Sri Lankan waters. Similar studies were also conducted in Indonesia, e.g. Fakhri et al. (2015) revealed no differentiated population of skipjack from western and eastern part of Bali. A different approach was 
used by (Wujdi et al., 2017) in order to distinguish skipjack stock in south part of Indonesian waters using otolith shapes. The study concluded a single population throughout southern part of Indonesian waters. However, a much broader skipjack genetic stock structure study is required to fully understand about the possibility of any distinguishable stocks between western and southern part of Indonesian waters. The result hopefully can be a foundation of any stock assessment of skipjack tuna in the future.

\section{Material and Methods}

Samples of skipjack were collected from 6 landing sites. Two from western part of Sumatra, e.g. Sibolga (SB), Padang (PD), and the rest (4) from south of Java, Bali and Nusa Tenggara, e.g. Binuangeun (BN), Pacitan (PC), Lombok (LO) and Kupang (KU) (Figure 1.) during July-August 2017. In order to reduce bias, only FAD's associated, fresh landed and small sized skipjack were chosen $(<30$ $\mathrm{cm}$ ), under assumption that small fishes' movement is still limited. Total genomic DNA (20 samples from each location) was extracted from muscular body tissue (Table 1.) and stored in absolute alcohol.

\section{DNA extraction}

Approximately every $0.2 \mathrm{~mm}$ of muscular tissue was transferred into an eppendorf tube contained $200 \mu \mathrm{l}$ of $10 \%$ chelex solution in $\mathrm{ddH}_{2} \mathrm{O}$ and resin solution (Walsh et al., 1991), it later mixed using vortex for 1 minute. The solution was centrifuged at $10,000 \mathrm{rpm}$ for 1 minute using microcentrifuge and incubated for 40 minutes at $95^{\circ} \mathrm{C}$ using a heating block or thermo shaker. The sample was mixed again using vortex for 1 minute and centrifuged for 1 minute at $10,000 \mathrm{rpm}$. DNA samples in the form of supernatants were taken and stored in a refrigerator at $-20^{\circ} \mathrm{C}$ until further use.

\section{PCR amplification}

Microsatellite markers used for this study referred to previous work by Dammannagoda et al. (2011). Three tetra-nucleotide microsatellite loci (UTD172, UTD535, and UTD523) were amplified and analyzed here. UTD172 (Forward: 5'-GTT GTG TAT TGG CTG GAC C-3 'TTT; Reverse: 5'-CAA CAG CT GGC AAA TTC CG-3'), UTD 523 (Forward: 5'-TTT GAA TGG GAG ACA TGC AG -3 '; Reverse: 5'-TGT CCT GCA CTT GTG TTC ACT -3') and UTD 535 (Forward: 5'- CAC TGA AGA TAT AGG CAG CCT TG -3 '; Reverse: 5'- TTT CTC CAG CGG CAT TAC AT -3'). Microsatellite PCR reaction consisted of $10 \mu \mathrm{l}$ HotStar $^{\circledR}$ Master Mix, $2 \mu \mathrm{l}$ sterilized water, $1 \mu \mathrm{l}$ primer $\mathrm{F}, 1 \mu \mathrm{l}$ primary $\mathrm{R}, 6 \mu \mathrm{l}$ DNA template. PCR conditions were as follow: predenaturation phase $\left(3\right.$ minutes at $\left.94^{\circ} \mathrm{C}\right)$, denaturation (30 seconds at $\left.94^{\circ} \mathrm{C}\right)$, primer attachment/annealing (30 seconds at $\left.52^{\circ} \mathrm{C}\right)$, fragment lengthening/extension $\left(1\right.$ minute at $\left.72^{\circ} \mathrm{C}\right)$.

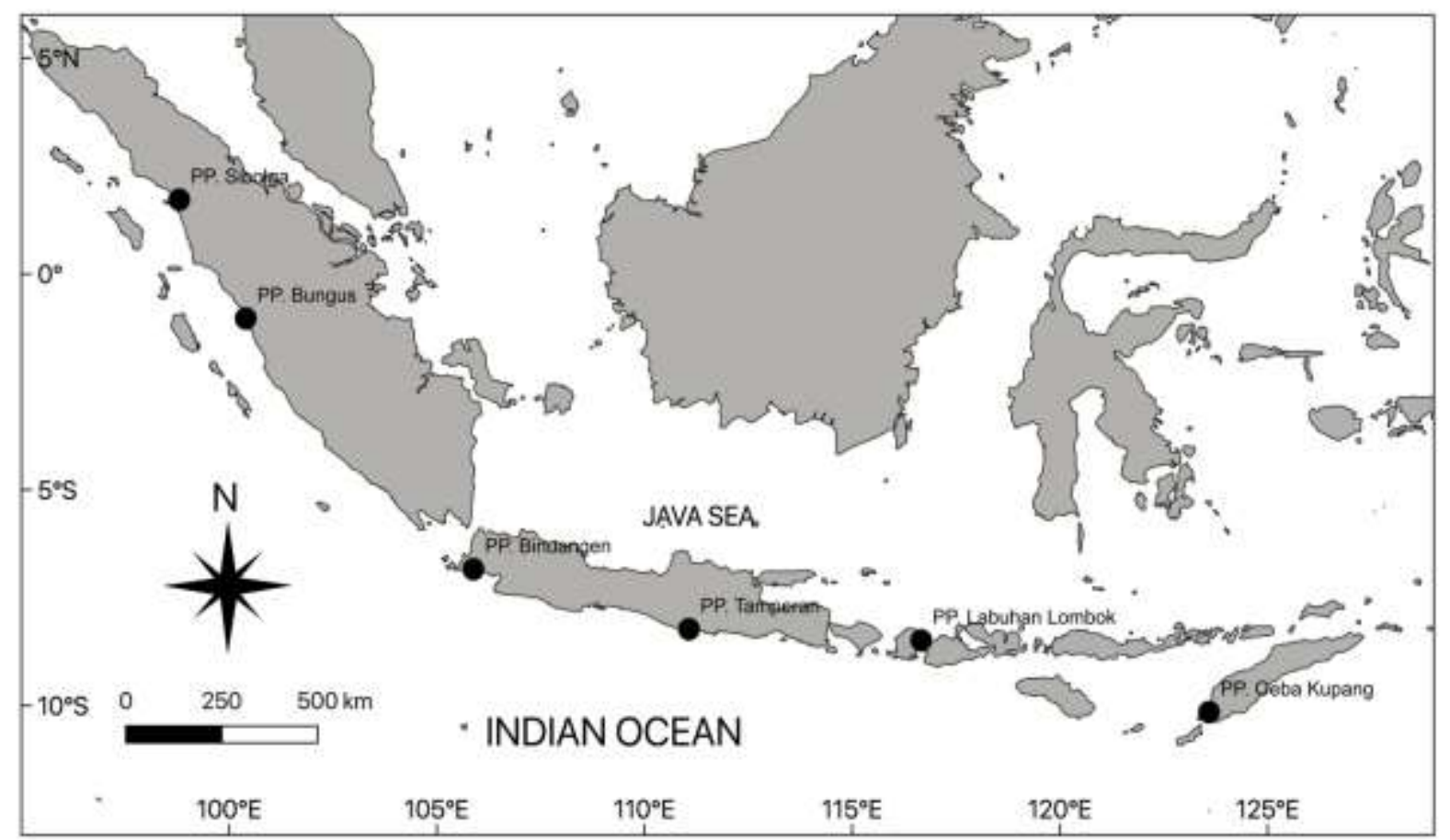

Figure 1. Skipjack tuna (K. pelamis) sampling sites in Southern and Western Part of Indonesian Waters 
All cycles were repeated 34 times. In order to improve the result, the final elongation stage/final extension was carried out for 10 minutes at $72^{\circ} \mathrm{C}$ and stored at room temperature $\left(\sim 24^{\circ} \mathrm{C}\right)$ for 1 minute.

\section{Electrophoresis}

Electrophoresis was performed on 1.5\% agarose gel in 10x TBE buffer, at $100 \mathrm{~V}$, with electric current $400 \mathrm{~mA}$ for 30 minutes. The DNA fragments visualized using an ultraviolet (UV) transilluminator and documented with a digital camera using the UVITEC $^{\circledR}$ device.

\section{Data analysis}

Analysis of DNA fragments was detected by the Applied Biosystems Genetic Analyzer ${ }^{\circledR}$ and then interpreted using the GeneMapper v4.0. This is required to clarify the interpretation of the DNA fragments' size (alleles) that appeared from each DNA genome. The 2-D look describe the allele's size (X-axis) and peak height (Y-axis) which showed the concentration of the results of the fragment analysis. The fragment analysis process was conducted at $1^{\text {st }}$ BASE Laboratory in Singapore. Each locus and each site were tested for deviation from Hardy-Weinberg equilibrium (HWE) in poppr package (Kamvar et al., 2014; Kamvar et al., 2015) under R version 3.5.0 (R Core Team, 2018) with significance of deviations in observed vs. expected heterozygosity tested using Chi-square. DNA diversity (molecular diversity indices), inbreeding coefficient $\left(F_{I S}\right)$ for each locus and each site and differentiation in population which determined the stock structure were tested using Arlequin v3.5 (Excoffier and Lischer, 2010). Analysis of Molecular Variance (AMOVA) was performed to determine the genetic variation and population structure among the skipjack population group.

\section{Results and Discussion}

\section{Genetic variability and Hardy-Weinberg equilibrium}

Genetic analyses were conducted on 120 individuals sampled from Sumatra (Sibolga, SB; Padang, PD), Java (Binuangeun, BN; Pacitan, PC), Nusa Tenggara Barat (Lombok, LO) and Nusa Tenggara Timur (Kupang, KU) (Figure 1). No null alleles, a total of 353 alleles were produced from 3 microsatellite loci across 6 sampling sites, with average abundance 23.56/site. Since all the data was diploid and the number of samples every location is similar, hence, number of multilocus genotype $(M L G)$, diversity index $(h)$ and eveness index (E.5) resulted the same (Table 1.). Sample populations were then tested for conformation to HWE. Both the analytical p-value and permuted $\mathrm{p}$ value showed enough confidence that all loci are not under the null expectation of HWE $(P>0.001)$. Therefore, all three loci were therefore included in all further analyses. The genetic diversity of each group/population was represented by the value of heterozygosity/expected heterozygosity $\left(H_{e}\right)$. The lowest mean abundance value of $H_{e}$ was found in Binuangen (0.6735), as the highest was in Sibolga (0.8557) (Table 2.).

\section{Population structure}

Pairwise distance test between the population $\left(F_{\mathrm{ST}}\right)$ and AMOVA were performed in order to investigate whether there are any differences in skipjack population structure. FSt value among the sample groups in all microsatellite loci were calculated under $99.95 \%$ confidence interval $(P<0.05)$. Pairwise $F_{\mathrm{St}}$ analysis of microsatellite data identified three different group of populations, PD and SB, BN and PC, LO, and KU (Table 3.).

Table 1. Sampling details and descriptive microsatellite statistics for skipjack tuna samples

\begin{tabular}{lcccccccccccc}
\hline \multicolumn{1}{c}{ Population } & $n$ & MLG & eMLG & se & \multicolumn{1}{l}{$h$} & \multicolumn{1}{l}{ G } & lambda & E.5 & Hexp & la & rbarD \\
\hline Lombok & 20 & 20 & 20 & 0 & 3 & 20 & 0.95 & 1 & 0.781 & -0.0159 & -0.00884 \\
Padang & 20 & 20 & 20 & 0 & 3 & 20 & 0.95 & 1 & 0.823 & 0.0223 & 0.02263 \\
Sibolga & 20 & 20 & 20 & 0 & 3 & 20 & 0.95 & 1 & 0.845 & -0.2119 & -0.11591 \\
Binuangen & 20 & 20 & 20 & 0 & 3 & 20 & 0.95 & 1 & 0.664 & -0.1084 & -0.05442 \\
Pacitan & 20 & 20 & 20 & 0 & 3 & 20 & 0.95 & 1 & 0.755 & 0.0793 & 0.04815 \\
Kupang & 20 & 20 & 20 & 0 & 3 & 20 & 0.95 & 1 & 0.75 & -0.1298 & -0.06905 \\
\hline Total & 120 & 120 & 20 & 0 & 4.79 & 120 & 0.992 & 1 & 0.794 & 0.0284 & 0.01507 \\
\hline
\end{tabular}

Note: Variables are represented by the following: $n$, sample size; $M L G$, Number of multilocus genotypes (MLG) observed; eMLG, The number of expected MLG at the smallest sample size $\geq 10$ based on rarefaction; se, standard error based on eMLG; $h$, Shannon-Wiener Index of MLG diversity (Shannon, 1948); G, Stoddart and Taylor's Index of MLG diversity (Stoddart \& Taylor, 1988); lambda, Simpson's Index (Simpson, 1949); E.5, Evenness Index, E5 (Grunwald et al., 2003; Ludwig and Reynolds, 1988; Pielou, 1976); Hexp, Nei's unbiased gene diversity (Nei, 1978); la, The index of association (Brown et al., 1980; Smith et al., 1993); rbarD, The standardized index of association. 
ILMU KELAUTAN: Indonesian Journal of Marine Sciences June 2019 Vol 24(2):61-68

Table 2. Descriptive statistics for three microsatellite loci among skipjack collections

\begin{tabular}{|c|c|c|c|c|c|}
\hline \multirow{2}{*}{ Location } & & \multicolumn{3}{|c|}{ Locus } & \multirow{2}{*}{ Mean across loci } \\
\hline & & UTD 172 & UTD 523 & UTD 535 & \\
\hline \multirow[t]{4}{*}{ Padang (PD) } & $n$ & 20 & 20 & 20 & 20 \\
\hline & $a$ & 2 & 30 & 40 & 24 \\
\hline & $\mathrm{He}_{\mathrm{e}}$ & 0.5128 & 0.9807 & 1.0000 & 0.8312 \\
\hline & $F_{I S}$ & -1.0000 & -0.0201 & -0.0201 & -0.3467 \\
\hline \multirow[t]{4}{*}{ Sibolga (SB) } & $n$ & 20 & 20 & 20 & 20 \\
\hline & $a$ & 4 & 26 & 38 & 22.66 \\
\hline & $H_{e}$ & 0.5923 & 0.9780 & 0.9960 & 0.8557 \\
\hline & $F_{I S}$ & -0.6298 & -0.0224 & -0.0228 & -0.6750 \\
\hline \multirow[t]{4}{*}{ Binuangeun (BN) } & $n$ & 20 & 20 & 20 & 20 \\
\hline & $a$ & 2 & 25 & 38 & 21.66 \\
\hline & $H_{e}$ & 0.5000 & 0.9731 & 0.9974 & 0.6735 \\
\hline & FIS & -0.0000 & -0.0284 & -0.0242 & -0.3912 \\
\hline \multirow[t]{4}{*}{ Pacitan (PC) } & $n$ & 20 & 20 & 20 & 20 \\
\hline & $a$ & 6 & 28 & 40 & 24.66 \\
\hline & $H_{e}$ & 0.3205 & 0.9769 & 1.0000 & 0.7658 \\
\hline & $F_{I S}$ & 0.0656 & -0.0243 & -0.0256 & 0.0052 \\
\hline \multirow[t]{4}{*}{ Lombok (LO) } & $n$ & 20 & 20 & 20 & 20 \\
\hline & a & 5 & 26 & 39 & 23.33 \\
\hline & $H_{e}$ & 0.3846 & 0.9795 & 0.9987 & 0.7876 \\
\hline & $F_{I S}$ & -0.1753 & -0.0215 & -0.0201 & -0.0723 \\
\hline \multirow[t]{4}{*}{ Kupang } & $n$ & 20 & 20 & 20 & 20 \\
\hline & a & 4 & 26 & 40 & 23.33 \\
\hline & $H_{e}$ & 0.3141 & 0.9756 & 1.0000 & 0.7633 \\
\hline & $F_{I S}$ & -0.1176 & -0.0256 & -0.0284 & 0.0573 \\
\hline
\end{tabular}

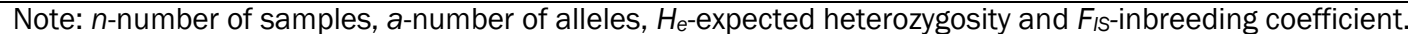

Table 3. Microsatellite pairwise $F_{S T}$ value among the sampling locations

\begin{tabular}{lllllll}
\hline Population & Padang & Sibolga & Binuangeun & Pacitan & Lombok & Kupang \\
\hline Padang & - & 0.4144 & $0,0001 * *$ & $0,0001 * *$ & $0,0001 * *$ & $0,0001 * *$ \\
Sibolga & 0.0000 & - & $0,0001 * *$ & $0,0001 * *$ & $0,0022 * *$ & $0,0001 * *$ \\
Binuangeun & 0.0956 & 0.0723 & - & $0,0180 *$ & $0,0006 * *$ & $0,0090 * *$ \\
Pacitan & 0.0696 & 0.0455 & 0.0122 & - & 0,1801 & 0,1803 \\
Lombok & 0.0335 & 0.0166 & 0.0158 & 0.0032 & - & 0,1982 \\
Kupang & 0.0700 & 0.0476 & 0.0103 & 0.0031 & 0.0032 & - \\
\hline
\end{tabular}

Note: * $P<0.05 ; * * P<0.01$

Table 4. Population structure based on differences in genetic variation of skipjack populations (AMOVA)

\begin{tabular}{cccccc}
\hline No. & Group simulations & Variance among groups & \% variance & FCT & $p$ value \\
\hline 1 & (PD,SB); (BN,PC,LO,KU) & 0,066 & 5,441 & 0,054 & $0,016 * *$ \\
2 & (PD,SB); (BN,PC); (LO,KU) & 0,045 & 3,804 & 0,038 & $0,039 * *$ \\
3 & (PD,SB); BN; PC; (LO,KU) & 0,046 & 3,866 & 0,039 & $0,010 * * *$ \\
4 & (PD,SB); BN; PC; LO; KU & 0,044 & 3,893 & 0,037 & $0,021 * *$ \\
\hline Note: ** P<0.05**** P<0.01 & & & &
\end{tabular}

The result then simulated into various group and analyzed with AMOVA. Among 4 group simulated, significant differentiation was evident among populations within locations. Group number 1 (PD,
SB and BN, PC, LO, KU) showed the highest variance among other groups (Table 4.). Therefore, rather than divided into 3 populations as a result from microsatellite pairwise, we chose the output from 
AMOVA analysis, which the populations were separated into two main group.

By far, the skipjack in Indian Ocean are currently managed as a single stock, yet previous and recent study strongly suggested some mixed stocks exist in Sri Lankan waters (Dammannagoda et al., 2011) and southern part of Indonesian waters. Intensive fishing pressure on particular fish stock known could cause population subdivision, lower genetic variation and produce selective genetic alteration (Allendorf et al., 2008). Latest report shown that total catches in 2017 (524,282 t) were $10 \%$ higher than the catch limit generated by the Harvest Control Rule (470,029 t) (IOTC, 2018). Although no sign of overfished or overfishing in the process. But it could be one of the intrinsic factors related to stock separation in Indian Ocean.

Most of skipjack fishing are assisted with FADs, especially in coastal areas (Davies et al., 2014; Marsac et al., 2017; Rodriguez-Tress et al., 2017). Since the successful implementation of anchored FAD for commercial purpose in 1985 (Yusfiandayani et al., 2015), it has been used intensively in western part of Sumatra and south of Java waters. Skipjack known to travel long and fast, for instance, based on recent tagging study, it could reach average distance of $800 \mathrm{~km}$ in just a month after release (Fonteneau, 2014). But, the long use of FAD could alter the behavior of skipjack, the present of 4-5 FAD in $50 \times 50 \mathrm{~km}$ area could hold the movement of skipjack up to $50 \%$ (Kleiber and Hampton, 2011) although not for a long period of time (Govinden et al., 2013). A theory developed by Marsac et al. (2000), and later discussed by Hallier and Gaertner (2008) suggested, that both type of FADs (drifting or anchored) are acting as a superstimulus, which misleading tunas to make inappropriate habitat selection or mostly known as ecological trap.

In this study, pairwise distance test suggested 3 distinguishable population of skipjack, 1 population in the west, and 2 separate populations in south (Table 2.). However, further analysis using AMOVA suggested only 2 distinguishable populations based on the highest variance percentage among group scenarios. The later result was more reasonable since there is no geographical barrier between two sites and located relatively close distance. The rough distance between BN and PR is around $555 \mathrm{~km}$, a reachable distance for skipjack based on tagging study (Fonteneau, 2014). Moreover, most of the genetic samples were derived from troll and handline fisheries, which their fishing grounds are located inside the EEZ. So, there is no strong motivation to distinguish the population of skipjack in southern of Indonesia to more than one.
Allele size distribution in this study is similar with (Dammannagoda et al., 2011), most likely due identical markers used. Loci UTD-523 and UTD-535 were highly polymorphic across skipjack samples, while loci UTD-172 was less polymorphic. Genetic polymorphism promotes diversity, and diversity means stability within population. Overall, skipjack population showed a high level of genetic diversity (mean $\mathrm{He}=0.780$ ), despite area around western part of Sumatra and southern part of Jawa, Bali and Nusa Tenggara known as intensive fishing ground of skipjack. This condition occurred, perhaps due to continuous gene flow from other areas, such as western Indian Ocean and archipelagic waters (Banda Sea) (Natsir et al., 2012; Fonteneau and Hallier, 2015). Higher allelic skipjack diversity is maintained by its large population throughout the world (Avise et al., 1998; Chiang et al., 2008), it also a typical of genetic pattern from Scombridae family (Zardoya et al., 2004). However, among all locations, Binuangen has the lowest genetic diversity, the cause is still unclear, but localized depletion from both troll line/hand line and purse seine fleets might be the cause. It is understood that above-mentioned fleets are sharing the same fishing ground, around the FADs. Continuous harvesting from the same FADs without giving time to replenish the stock could provoke growth overfishing on skipjack. Naturally, during November to March the effort will drop due to bad weather condition triggered by monsoon season. During this time, skipjack will have enough time to rejuvenate themselves. But in Binuangen, the fishing happens all year despite the monsoon period, resulted in small skipjack caught during the particular period. An open close system perhaps is the viable solutions for both conservation and exploitation purpose. Maintaining high genetic diversity is key to sustainability. Populations with high genetic diversity have a better chance of survival because each gene has a different response to environmental conditions. The presence of various genes from individuals in the population increases the ability of the population to respond to environmental changes (Wright, 2005).

\section{Conclusion}

This study reveals that there are two stocks of skipjack tuna in Indonesian waters, in Indian Ocean area, i.e. west of Sumatera waters and south of Java waters. This finding in line with Indonesian Fisheries Management Area of 572 (west of Sumatera waters) and 573 (south of Java waters). However, as highly migratory species across nations, the management strategy for skipjack tuna needs collaboration among countries through regional fisheries management authority like IOTC. 


\section{References}

Allendorf, F.W., England, P.R., Luikart, G., Ritchie, P.A. \& Ryman, N. 2008. Genetic effects of harvest on wild animal populations. Trends in Ecol. Evol. 23(6): 327-337.

Avise, J.C., Walker, D. \& Johns, G.C. 1998. Speciation durations and Pleistocene effects on vertebrate phylogeography. Proc. Royal Soc. London. 265(1407): 1707-1712. doi: 10.1098/rspb.1998.0492.

Barth, J.M.I., Damerau, M., Matschiner, M., Jentoft, S. \& Hanel, R. 2017. Genomic differentiation and demographic histories of atlantic and indopacific yellowfin tuna (Thunnus albacares) populations. Genome Biol. Evol. 9(4):10841098. doi: 10.1093/gbe/evx 067

Brown, A.H.D., Feldman, M.W. \& Nevo, E. 1980. Multilocus structure of natural populations of Hordeum spontaneum. Genetics. 96(2):523536.

Chiang, H.C., Hsu, C.C., Wu, G. C.C., Chang, S.K. \& Yang, H.Y. 2008. Population structure of bigeye tuna (Thunnus obesus) in the Indian Ocean inferred from mitochondrial DNA. Fish. Res. 90(1-3): 305-312.

Dammannagoda, S.T., Hurwood, D.A. \& Mather, P.B. 2011. Genetic analysis reveals two stocks of skipjack tuna (Katsuwonus pelamis) in the northwestern Indian Ocean. Can. J. Fish. Aqua. Sci. 68(2):210-223. doi: 10.1139/ F10-136.

Davies, T.K., Mees, C.C. \& Milner-Gulland, E.J. 2014. The past, present and future use of drifting fish aggregating devices (FADs) in the Indian Ocean. Mar. Pol. 45:163-170. doi: 10.1016/j.marpol. 2013.12.014.

Ely, B., Viñas, J., Bremer, J.R.A., Black, D., Lucas, L., Covello, K. \& Thelen, E. 2005. Consequences of the historical demography on the global population structure of two highly migratory cosmopolitan marine fishes: the yellowfin tuna (Thunnus albacares) and the skipjack tuna (Katsuwonus pelamis). BMC Evolution. Biol. 5(1):19. doi: 10.1186/1471-2148-5-19.

Excoffier, L. \& Lischer, H.E. 2010. Arlequin suite ver 3.5: a new series of programs to perform population genetics analyses under Linux and Windows. Mol. Ecol. Res. 10(3): 564-567. doi: 10.1111/j.1755-0998.2010.02847.x.

Fakhri, F., Narayani, I. \& Mahardika, I.G.N.K. 2015. Genetic diversity of skipjack tuna (Katsuwonus pelamis) from Jembrana and Karangasem Regencies, Bali. J. Biologi, 19(1): 11-14.

Fonteneau, A. 2014. On the movements and stock structure of skipjack (Katsuwonus pelamis) in the Indian Ocean. IOTC-2014-WPTT16-36, 16 p.

Fonteneau, A. \& Hallier, J.P. 2015. Fifty years of dart tag recoveries for tropical tuna: a global comparison of results for the western Pacific, eastern Pacific, Atlantic, and Indian Oceans. Fish. Res. 163:7-22.

Fujino, K., Sasaki, K. \& Okumura, S.I. 1981. Genetic diversity of skipjack tuna in the Atlantic, Indian, and Pacific Oceans. Bull. Japan. Soc. Sci. Fish. 47(2): 215-222.

Govinden, R., Jauhary, R., Filmalter, J., Forget, F., Soria, M., Adam, S. \& Dagorn, L. 2013. Movement behaviour of skipjack (Katsuwonus pelamis) and yellowfin (Thunnus albacares) tuna at anchored fish aggregating devices (FADs) in the Maldives, investigated by acoustic telemetry. Aquatic Living Res. 26(1): 69-77. doi: 10.1051/alr/2012022.

Grande, M., Murua, H., Zudaire, I., Goni, N. \& Bodin, N. 2014. Reproductive timing and reproductive capacity of the skipjack tuna (Katsuwonus pelamis) in the western Indian Ocean. Fish. Res. 156:14-22. doi: 10.1016/j.fishres.2014. 04.011.

Graves, J.E., Ferris, S.D. \& Dizon, A.E. 1984. Close genetic similarity of Atlantic and Pacific skipjack tuna (Katsuwonus pelamis) demonstrated with restriction endonuclease analysis of mitochondrial DNA. Mar. Biol. 79(3):315-319.

Grunwald, N.J., Goodwin, S.B., Milgroom, M.G. \& Fry, W.E. 2003. Analysis of genotypic diversity data for populations of microorganisms. Phytopathology. 93(6): 738-746. doi: 10.1094 /PHYTO.2003.93.6.738.

Hallier, J. \& Gaertner, D. 2008. Drifting fish aggregation devices could act as an ecological trap for tropical tuna species. Mar. Ecol Prog. Ser. 353:255-264. doi: 10.3354/meps07180.

Indian Ocean Tuna Commission. 2018. Report of the 20th Session of the IOTC Working Party on Tropical Tunas (No. IOTC-2018-WPTT20R[E]). Seychelles: Indian Ocean tuna Commission (IOTC). $131 \mathrm{p}$.

Iranawati, F. 2014. An assessment of the geographical scale of recurrent gene flow in wild 
populations of two species of Mekong River carps (Henicorhynchus spp.) (PhD Thesis). Queensland University of Technology, Australia.

Jatmiko, I., Rochman, F. \& Agustina, M. 2018. Genetic variation of yellowfin tuna (Thunnus albacares; Bonnaterre, 1788) with microsatellite analysis in Indonesian waters. J. Penelitian Perikanan Ind. 24(2): 157-164.

Jatmiko, I., Hartaty, H. \& Bahtiar, A. 2015. Reproductive biology of skipjack tuna (Katsuwonus pelamis) in Eastern Indian Ocean. Bawal Widya Riset Perikanan Tangkap. 7(2):87-94.

Jin, S., Yan, X., Zhang, H. \& Fan, W. 2015. Weightlength relationships and Fulton's condition factors of skipjack tuna (Katsuwonus pelamis) in the western and central Pacific Ocean. PeerJ. 3: e758. doi : 10.7717/peerj.758.

Kamvar, Z.N., Brooks, J.C. \& Grunwald, N.J. 2015. Novel $\mathrm{R}$ tools for analysis of genome-wide population genetic data with emphasis on clonality. Frontiers in Genetics. 6: 208.

Kamvar, Z.N., Tabima, J.F. \& Grunwald, N.J. 2014. Poppr: an R package for genetic analysis of populations with clonal, partially clonal, and/or sexual reproduction. PeerJ. 2: e281.

Kleiber, P. \& Hampton, J. 2011. Modeling effects of FADs and islands on movement of skipjack tuna (Katsuwonus pelamis): estimating parameters from tagging data. Can. J. Fish. Aqua. Sci. 51(12):2642-2653. doi: 10.1139/ f94-264.

Ludwig, J.A. \& Reynolds, J.F. 1988. Statistical ecology: a primer in methods and computing. New York, USA: John Wiley \& Sons. 337p.

Marsac, F., Fonteneau, A., Lucas, J., Báez, J.C. \& Floch, L. 2017. Data-derived fishery and stocks status indicators for skipjack tuna in the Indian Ocean. IOTC-2017-WPTT19-43.

Marsac, F., Fonteneau, A. \& Menard, F. 2000. Drifting FADs used in tuna fisheries: an ecological trap? Retrieved from https://archimer.ifremer.fr/doc/00042/15303

Menezes, M.R., Ikeda, M. \& Taniguchi, N. 2006. Genetic variation in skipjack tuna Katsuwonus pelamis (L.) using PCR-RFLP analysis of the mitochondrial DNA D-loop region. J. Fish Biol. 68(A):156-161. doi: 10.1111/j.1095-8649. 2006.00993.
Natsir, M., Widodo, A. \& Prisantoso, B. I. (2012). Fishing activity, size distribution, tag released and recapture of tuna tagging in eastern Indonesian waters. Ind. Fish. Res. J. 18(1): 47 56. doi: 10.15578/ifrj.18.1.2012.47-56.

Nei, M. 1978. Estimation of average heterozygosity and genetic distance from a small number of individuals. Genetics. 89(3): 583-590.

Nurdin, E. \& Nugraha, B. 2008. Catch of tuna and skipjack with hand line based in fish landing of Pondokdadap, Sendang Biru, Malang. Bawal Widya Riset Perikanan Tangkap. 2(1): 27-33.

Pielou, E.C. 1976. Ecological diversity. New York, USA: John Wiley \& Sons. 165 p.

R Core Team. 2018. R: A Language and Environment for Statistical Computing. Vienna, Austria: R Foundation for Statistical Computing. Retrieved from https://www.R-project.org/.

Rochman, F., Nugraha, B. \& Wujdi, A. 2015. The estimation on population parameters of skipjack (Katsuwonus pelamis, Linnaeus, 1758) in the Indian Ocean, south of Java. BAWAL Widya Riset Perikanan Tangkap. 7(2): 77-85.

Rodriguez-Tress, P., Capello, M., Forget, F., Soria, M., Beeharry, S. P., Dussooa, N. \& Dagorn, L. 2017. Associative behavior of yellowfin Thunnus albacares, skipjack Katsuwonus pelamis, and bigeye tuna $T$. obesus at anchored fish aggregating devices (FADs) off the coast of Mauritius. Mar. Ecol. Prog. Ser. 570: 213-222. doi: 10.3354/meps12101

Satria, F. \& Sadiyah, L. 2018. The development of harvest strategies for tropical tuna in Indonesia's achipelagic waters. Ind. Fish. Res. J. 24(1): 39-48. doi: 10.15578/ifrj.24.1.2018. 53-63.

Setiyawan, A. 2016. The estimation of skipjack utilization rate in Prigi waters, East Java. DEPIK 5(1):7-11. doi: 10.13170/depik. 5.1.3831.

Setyadji, B., Pranowo, W.S. \& Amri, K. 2018. Sea-air impacts on fishing season of hand line skipjack tuna Katsuwonus pelamis (Linnaeus, 1758) in Pacitan coastal waters of the south eastern Indian Ocean. Omni-Akuatika. 14(1):1-10.

Shannon, C.E. 1948. A mathematical theory of communication. Bell System Technical J. 27(3): 379-423.

Simpson, E.H. 1949. Measurement of diversity. Nature. 163: 688. 
Smith, J.M., Smith, N.H., O'Rourke, M. \& Spratt, B.G. 1993. How clonal are bacteria? Proc. National Academy Sci. 90(10):4384-4388.

Stoddart, J.A. \& Taylor, J.F. 1988. Genotypic diversity :estimation and prediction in samples. Genetics. 118(4):705-711.

Walsh, P.S., Metzger, D.A. \& Higuchi, R. 1991. Chelex 100 as a medium for simple extraction of DNA for PCR-based typing from forensic material. Biotechniques. 10(4): 506-513.

Wright, A.F. 2005. Genetic variation: polymorphisms and mutations. In: ELS. John Wiley \& Sons Ltd, Chichester. doi : 10.1038/npg.els. 0005005

Wujdi, A., Setyadji, B. \& Nugroho, S C. 2017. Stock structure identification of skipjack tuna (Katsuwonus pelamis Linnaeus, 1758) in Indian Ocean (Indonesian territory of FMA 573) using otolith shape analysis. J. Penelitian Perikanan Ind. 23(2):77-88.
Yusfiandayani, R., Baskoro, M.S. \& Monintja, D. 2015. Impact of fish aggregating device on sustainable capture fisheries. KnE Life Sci. 1: 224-237. doi : 10.18502/kls.v1i0.107

Zardoya, R., Castilho, R., Grande, C., Favre-Krey, L., Caetano, S., Marcato, S., Krey, G. \& Patarnello, T. 2004. Differential population structuring of two closely related fish species, the mackerel (Scomber scombrus) and the chub mackerel (Scomber japonicus), in the Mediterranean Sea: Population Structure of Mediterranean Sea Scomber spp. Mol. Ecol. 13(7): 17851798. doi:10.1111/j.1365-294X.2004.0219 $8 . x$

Zedta, R.R., Rintar, P.A. \& Novianto, D.N. 2018. Population parameters estimation of skipjack tuna (Katsuwonus pelamis, Linnaeus, 1758) in Indian Ocean. BAWAL Widya Riset Perikanan Tangkap. 9(3): 163-173. doi: 10.15578/ bawal.9.3.2017.163-173. 